Reprod. Nutr. Dévelop., 1985, 25 (2), 399-410.

\title{
Addition of sorbitol to a milk substitute for veal calves. - I. Effects on health, growth and feed conversion
}

\author{
D. BAUCHART, B. AUROUSSEAU, E. AUCLAIR
}

With the technical assistance of Marinette MARTINAUD

C. LEOTY, R. MARPILLAT $(*)$, J. MOULY $(*)$ and R. SOUCHET

Laboratoire d'Etude du Métabolisme énergétique.

$\left(^{*}\right)$ Laboratoire de la Digestion des Ruminants, I.N.R.A., Theix, 63122 Ceyrat, France.

Summary. Two homologous groups of preruminant male calves $(10$ control and 9 sorbitol) of the Friesian $\times$ Holstein crossbreed were used to study the effects of sorbitol on appetite, health status and growth rate. Between 1 and 8 weeks of age they were given two milk replacers (IC and IS) that contained high levels of protein and fat (23\% of DM), and then between 8 and 19 weeks two diets (FC and FS) containing lower levels of protein and fat (21\% of DM). The IC and FC diets had no sorbitol, while in the IS and FS diets it accounted for $0.8 \%$ of DM. In each group 4 to 6 calves were used to measure milk digestibility at 3,7 and 12 weeks of age. At slaughter (19 weeks), carcass quality and liver status were checked.

The overall health status of the animals was satisfactory, but after accidental cold stress at week 7, the 10 calves of the control group had diarrhea for 2 to 5 days vs 4 calves in the sorbitol group.

Sorbitol digestibility was about $95 \%$ at week 3 and almost $100 \%$ at weeks 7 and 12 . Apparent energy and protein digestibilities increased in the two lots from 83.8 and 83.1, respectively, at week 3 , to 89.8 and $90.7 \%$, respectively, at week 7 , but these digestibilities were not affected by sorbitol.

Liveweight gain $(+12 \%$ for the whole trial) and feed efficiency $1+6.7 \%$ for the whole trial) were significantly $(P<0.05)$ improved by the presence of sorbitol in the diet.

\section{Intoduction.}

Sorbitol is found throughout nature, namely in fruits (Watson and Yudkin, 1959). It is manufactured by the hydrogenation of glucose. When flowing into the human duodenum, this hexilic alcohol leads to the secretion and release of cholescytokinin pancreozymin (Moullart, 1959) and to accelerated intestinal peristaltism and digestive flow (Porcher, 1957). An excess of sorbitol can block gastrointestinal flow (Koopmans and Maggio, 1978).

In preruminant calves, dietary sorbitol increases the volume of bile and the quantity of excreted bile salts (Thivend et al., 1984). Moreover, it improves feed 
intake and the feed conversion ratio from birth to 3 weeks in calves given milk (75\% of food dry matter) and a concentrate (Daniels et al., 1981) or between the ages of 8 to 16 weeks in preruminant calves (Thivend, 1982). Thivend attributed the effect of sorbitol to the increased capacity of calves to deal with the fatigue caused by a high lipid intake. As in man, sorbitol could have a favorable effect on liver metabolism (Hoshi, 1963).

Owing to its effects on the digestive process and liver metabolism, sorbitol might solve two major problems one has to deal with in veal calf husbandry: limited lipid digestion during the first neonatal weeks and the risk of health disorders and stunted growth at the end of the fattening period due to high lipid intake.

The aim of this work was to study the effect of sorbitol intake on the digestion of the main constituents of milk and on daily liveweight gain and feed efficiency. The metabolic effects of dietary sorbitol will be presented separately (Bauchart et al., 1985).

\section{Material and methods.}

Animals and diets. - Nineteen crossbred Friesian-Holstein male calves received colostrum during the first $6 \mathrm{~h}$ after birth; they were divided into two groups according to age, birthweight, hematocrit and blood immunoglobulin level. From neonatal day 7 onwards, 10 calves received the control diets and $y$ the experimental diets supplemented with $0.8 \%$ sorbitol. They were housed on a litter of wood shavings in an air-conditioned shed (average temperature : $20^{\circ} \mathrm{C}$; hygrometric level : $80 \%$ ) and kept chained.

Milk replacers were bucket-fed in two equal meals per day at 8 a.m. and 4 p.m. From day 8 onwards the Sunday evening meal was omitted.

From the start of the experiment and until the calves were 8 weeks old, they received two diets (IC $=$ initial control ; IS $=$ initial sorbitol) with a high lipid content $(23 \%)$. Afterwards and until they were 19 weeks old, they were fed two diets (FC = finishing control ; FS = finishing sorbitol) with a lower lipid content $(21 \%)$ in order to allow a higher feeding schedule and a more rapid growth rate in older calves. Details of the ingredient mixture used in the four diets are given in table 1.

The daily rations of the milk replacer, more similar in both groups and on a dry-matter basis, amounted to about 1.8 to $2.1 \%$ of liveweight, and the liquid feeding scheme varied with animal liveweight throughout the experiment according to the recommendations of Toullec et al. (1978).

Ration and refusal weights were carefully recorded at every meal. The variations of feed intake with calf age are shown in figure 1. The calves were weighed on arrival in the shed and then at 2 p.m. every Friday afternoon up to the end of the experiment.

They were slaughtered at 19 weeks of age, and body weight and fattening, color and carcass conformation scores were assessed as well as the weight, color and general aspect of the liver. 
TABLE 1

Composition of the milk substitutes.

\begin{tabular}{lcccc}
\hline \multirow{2}{*}{ Diet } & \multicolumn{2}{c}{ Initial } & \multicolumn{2}{c}{ Finishing } \\
\cline { 2 - 5 } & Control (IC) & Sorbitol (IS) & Control (FC) & Sorbitol (FS) \\
\hline Constituents (\%) & & & & \\
Spray-dried skim milk powder & 68 & 68 & 60 & 60 \\
Spray-dried whey powder & - & - & 10 & 10 \\
Tallow & 23 & 23 & 21 & 21 \\
Maize starch (Amidor D (*)) & 6.8 & 6.0 & 6.8 & 6.0 \\
Dicalcium phosphate & 0 & 0.8 & 0 & 0.8 \\
Mineral and vitamin mixture & 1.0 & 1.0 & 1.0 & 1.0 \\
& 1.2 & 1.2 & 1.2 & 1.2 \\
\hline Chemical composition & & & & \\
Lipids (\% DM) & 23.0 & 23.0 & 21.0 & 21.0 \\
Protein (N $\times$ 6.25; \% DM) & 22.8 & 22.7 & 21.5 & 21.3 \\
Sorbitol (\% DM) & 0 & 0.8 & 0 & 0.8 \\
Gross energy (kcal/g DM) & 5.182 & 5.148 & 4.994 & 4.996 \\
\hline
\end{tabular}

(*) Roquette Frères Society, 62136 Lestrem, France.

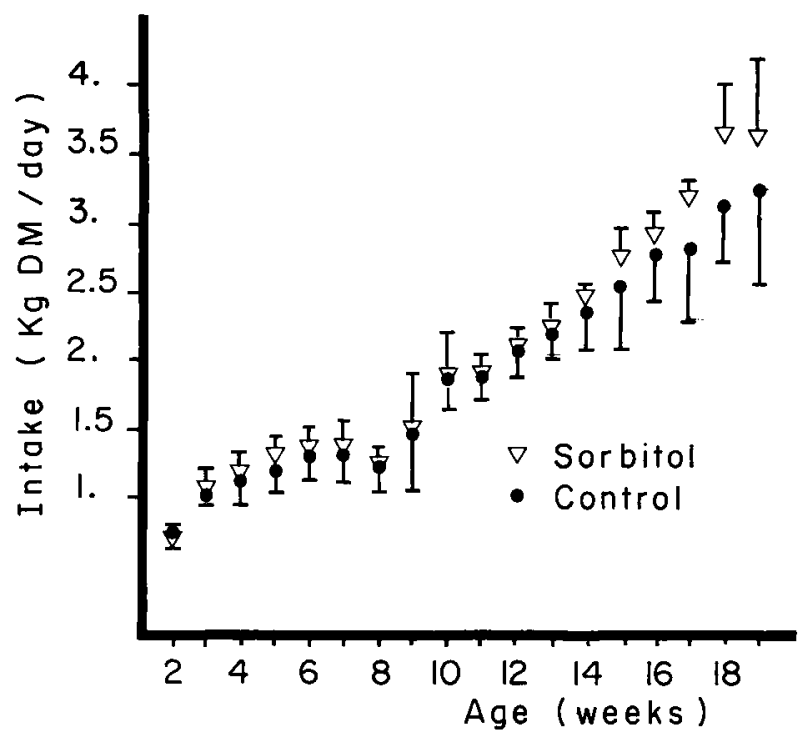

FIG. 1. - Intake (kg DM/day) of control and sorbitol milk substitute in veal calves during weeks 2 to 19 of age (mean \pm SD). 
Digestibility studies. - The apparent digestibility of the main constituents of the ration was obtained for 4 to 6 calves (table 5 ) in each group by collecting all the faeces in plastic bags fitted on the calves with a harness. The faeces were collected for 5 consecutive days at the ages of 3, 7 and 12 weeks. The samples (milk substitute and faeces) were treated and the dry matter (DM), organic matter $(\mathrm{OM})$, protein $(\mathrm{N} \times 6.25)$ and gross energy $(\mathrm{GE})$ analysed as described by Vermorel et al. (1973). The lipid content of the milk substitutes was measured according to the Folch method (Folch, Lees and Sloane-Stanley, 1957), but for the faeces it was estimated from the energy and protein contents since faecal lactose (Besle, Lassalas and Thivend, 1983) and starch (Thivend, 1979) are very low. Sorbitol was determined in aqueous extracts by colorometry after enzymatic action (sorbitol dehydrogenase, Boehringer).

\section{Results.}

Health and milk substitute intake. - Throughout the experiment, calf health was good and only a few cases of diarrhoea were observed. Moreover, the frequency of diarrhoea was lower $(P<0.05)$ in the sorbitol than in the control 10.55 vs 2.3 days of diarrhoea per animal) group (table 2). Following accidental cold stress when they were 7 weeks old, the 10 calves of the control group had diarrhoea but only 4 in the sorbitol group were afflicted. Similarly, during week 14, 7 calves of the control group and only 1 calf of the sorbitol group suffered from diarrhoea. Most of the animals were only slightly affected since the symptoms disappeared after a single day of vitamin B12-methionine treatment and after a rehydrating agent was given in 3 cases.

Two instances of pulmonary infection were observed in each group. They disappeared within 3 days after treatment with an antibiotic (Histabiozone). Finally, two cases of severe arthritis were observed in the control group but none in the sorbitol group. Even though this infection persisted for several weeks, it did not have any effect on food intake.

The frequency of refusals and the amount of milk refused for the entire experiment were about three times higher in the control than in the sorbitol group (P< 0.05). They were also higher in the first part of the experiment when the calves were offered milk replacers IC and IS characterized by a high lipid content (table 2).

Apparent digestibility $(D)$ of ration constituents. - There were no significant differences in apparent digestibility of the diet constituents (DM, OM, protein, lipid) between the two groups at any of the three age periods (table 3). Protein and lipid apparent digestibilities rose by about 9.1 and 6.5 points, respectively, between weeks 3 and 12 and were 91.6 and $90.5 \%$, repectively, at that time (table 3).

Standard errors were high at 3 weeks and dropped at 7 and 12 weeks. In other respects, the standard errors were lower in the sorbitol than in the control group during all three periods (table 3 ). 


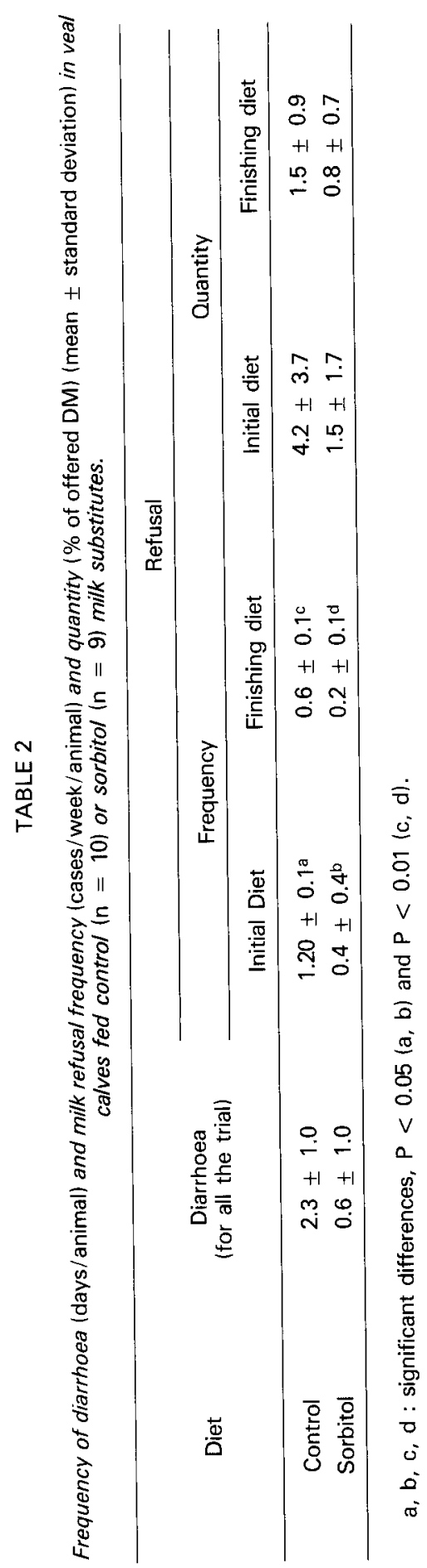

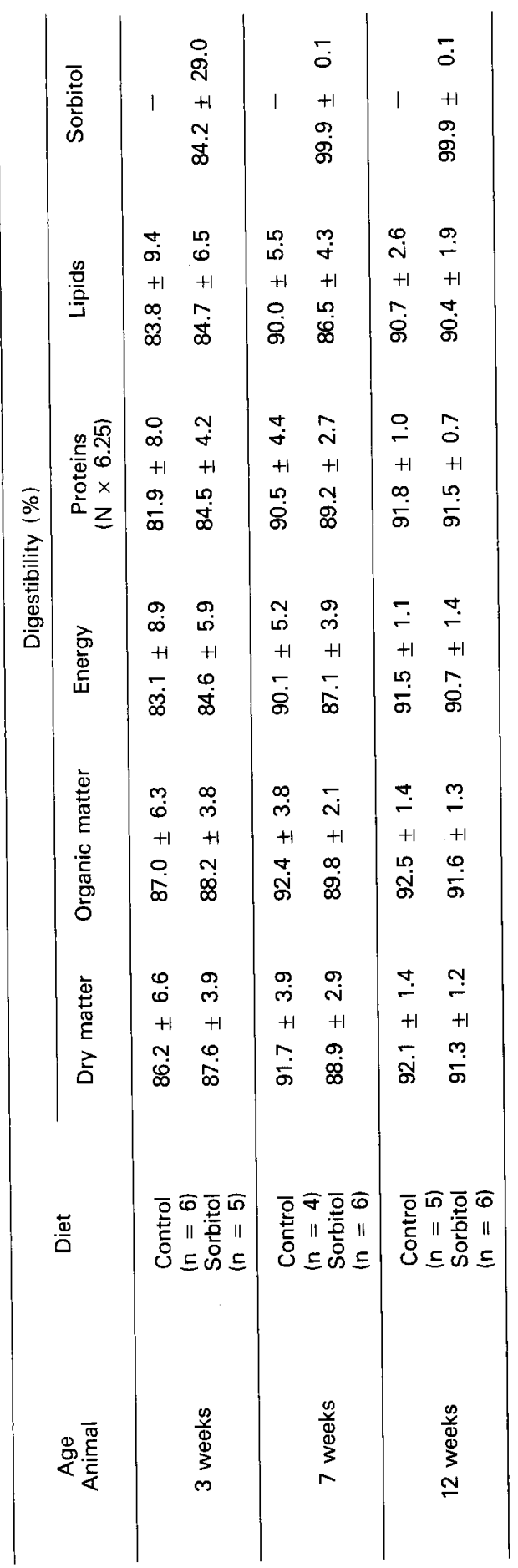




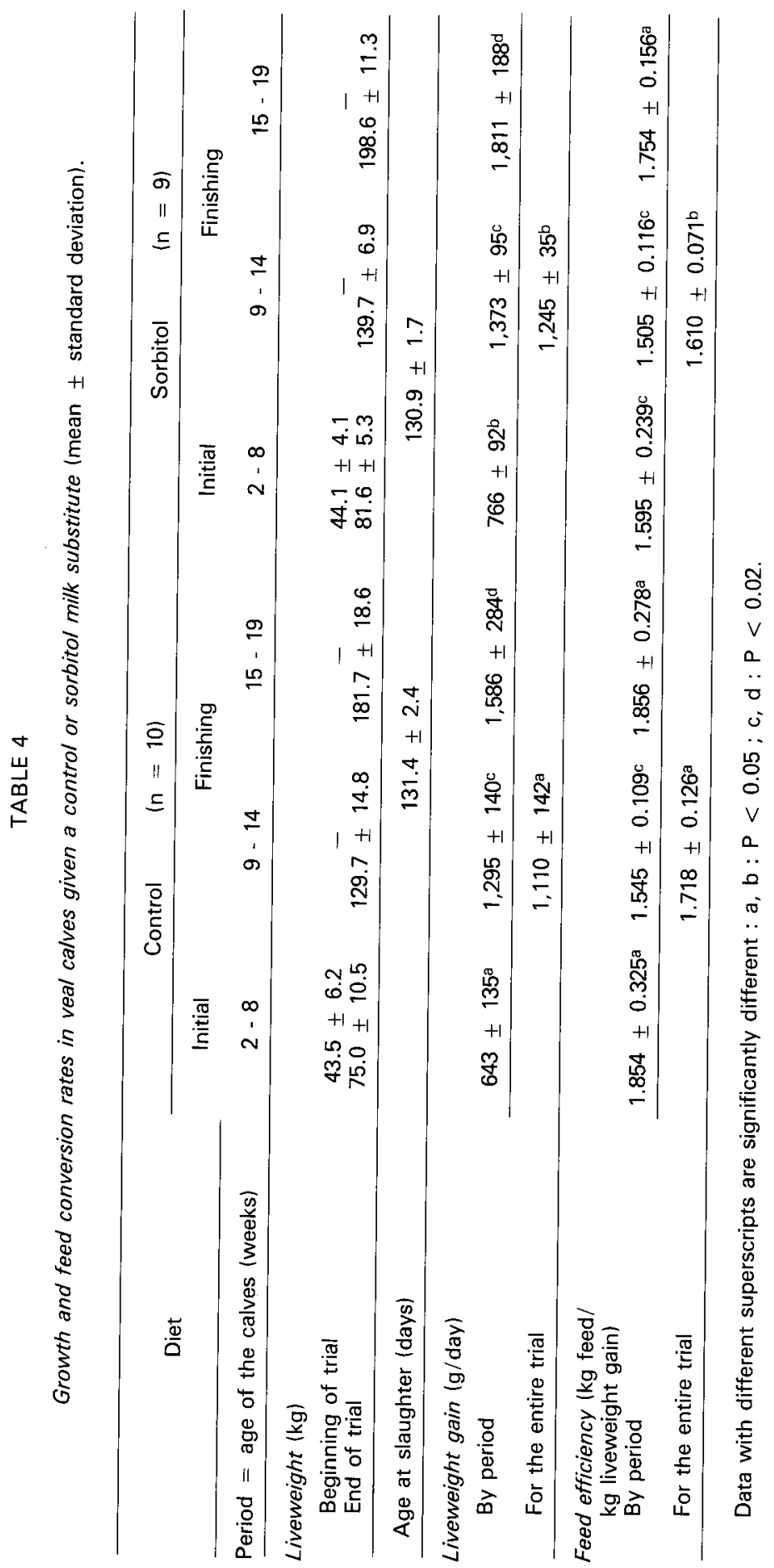


Growth and feed efficiency. - The feeding scheme of this experiment allowed for very high daily liveweight gains (over $1100 \mathrm{~g} / \mathrm{d}$ ) during the entire experiment in both groups (table 4). The overall daily liveweight gain was $12.1 \%$ higher (about $135 \mathrm{~g} / \mathrm{d} ; \mathrm{P}<0.05$ ) for calves fed sorbitol. The differences between the two groups were particularly high during the first period of the experiment when the calves received a high-lipid milk substitute. During that time the daily liveweight gain was $19.1 \%$ higher $(+123 \mathrm{~g} / \mathrm{d})$ for calves fed sorbitol. Differences were found again during the last 5 weeks of the experiment with a $14.2 \%$ higher daily liveweight gain $(+225 \mathrm{~g} / \mathrm{d})$ for calves fed sorbitol. During that time milk substitute intake was very high (table 4 ).

In the control group, individual liveweights were highly dispersed from the first weeks onwards (fig. 2a) when the calves received the high-lipid diet $(23 \%$ of DM). In the sorbitol group, liveweight variations were more homogeneous (fig. 2b), the standard errors being on the whole twice lower than in the control group, as during weeks 8,14 and 19 (table 4). At these three ages, mean liveweight was 8.8, 7.7 and $9.3 \%$ higher, respectively, in the sorbitol group (table 4).

Feed efficiency, expressed as $\mathrm{kg}$ feed $/ \mathrm{kg}$ liveweight gain, increased $(P<$ 0.02 ) in the calves fed sorbitol during the growth period but later on during the finishing period, sorbitol had no significant effects (table 4). During the whole trial sorbitol improved $(P<0.05)$ feed efficiency by about $6.7 \%$.

Carcass and liver characteristics. - At slaughter, carcass weight was $7.3 \%$ higher (non-significant) in the sorbitol group but there were no differences in color, conformation or fattening scores (table 5).

Sorbitol intake had no effect on the relative weight of the liver $1 \%$ of calf liveweight) (table 5). The color of the liver did not differ from that of the control group livers. In both groups liver aspect and firmness were good (table 5).

\section{TABLE 5}

Carcass and liver characteristics of slaughtered veal calves fed a control or sorbitol milk substitute (mean \pm standard deviation).

\begin{tabular}{|c|c|c|}
\hline & Control & Sorbitol \\
\hline \multicolumn{3}{|l|}{ Carcass } \\
\hline $\begin{array}{l}\text { Weight (kg) } \\
\text { Color (1) } \\
\text { Conformation (2) } \\
\text { Fattening score (3) }\end{array}$ & $\begin{array}{c}108.8 \pm 12.0 \\
2.10 \pm 0.32 \\
2.10 \pm 0.57 \\
3.00 \pm 0.47\end{array}$ & $\begin{aligned} & 116.7 \pm 7.7 \\
& 2.0 \pm 0.1 \\
& 2.11 \pm 0.33 \\
& 3.00 \pm 0.01\end{aligned}$ \\
\hline \multicolumn{3}{|l|}{ Liver } \\
\hline $\begin{array}{l}\text { Weight }(\mathrm{kg}) \\
\text { Weight }(\% \text { liveweight }) \\
\text { Color }(4) \\
\text { Aspect }(5)\end{array}$ & $\begin{array}{l}3.89 \pm 0.50^{\mathrm{a}} \\
2.10 \pm 0.25 \\
2.48 \pm 0.42 \\
3.10 \pm 0.99\end{array}$ & $\begin{array}{l}4.35 \pm 0.28 b \\
2.15 \pm 0.20 \\
2.11 \pm 0.59 \\
3.22 \pm 1.30\end{array}$ \\
\hline
\end{tabular}

(1) $1:$ white ; 4 : red. (2) $5:$ better ; 1 : passable. (3) 1 : lean ; 5 : very fat. (4) 1 : very clear ; 3 : red. (5) 4 : turgid ; 1 : flacid.

$a, b$ : significant differences at $P<0.05$. 

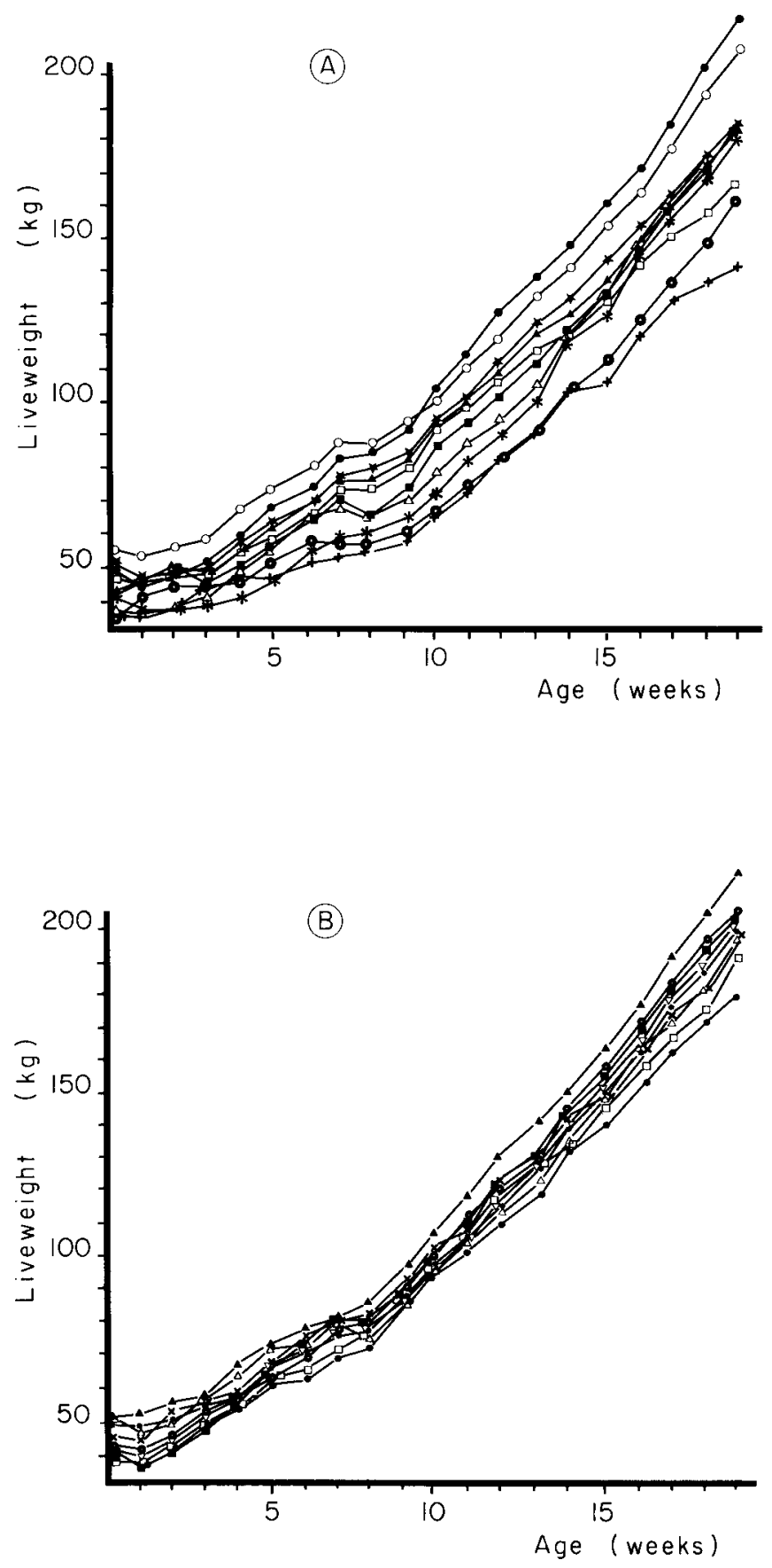

FIG. 2. - Age variations (weeks) in liveweight $(\mathrm{kg})$ of veal calves fed a control (A) or sorbitol (B) milk substitute from birth to slaughter (19 weeks). 


\section{Discussion.}

The intake of increasing amounts of sorbitol $(6$ to $29 \mathrm{~g} / \mathrm{d})$ in the course of this experiment helped to keep the calves healthy and active. During the entire experiment, the sorbitol group was more resistant to illness (pulmonary infection, arthritis), digestive disorders (diarrhoea) and metabolic load excess owing to the high intake level.

Sorbitol had no effect on the digestibility of the main constituents of the diet, namely of lipids, at any age, although Thivend et al. (1984) showed that the intake of $0.1 \mathrm{~g}$ of sorbitol $/ \mathrm{day} / \mathrm{kg}$ liveweight led to increases in bile volume and the amount of bile salts excreted. The increase of bile salt secretion was perhaps insufficient in our trial with an intake of $0.12-0.15 \mathrm{~g}$ sorbitol $/ \mathrm{day} / \mathrm{kg}$ liveweight (Thivend et al., 1984), since Kussaibati and Leclercq (1984) failed to notice any increase in lipid digestibility with sorbitol in chicks. Improved lipid digestibility with both diets as the calves grew older was very likely due to the progressive maturation of the pancreas (Huber, Jacobson and Allen, 1961), permitting the pancreatic juice to play an increasing role.

In agreement with the results obtained by Thivend (1982), sorbitol significantly improved the liveweight gain of the calves throughout the entire trial. This effect was namely brought about during the initial period ( 2 to 8 weeks) when the calves received a high-lipid diet (23\% DM) and were given a high feeding level, two conditions believed to have an unfavorable influence on calf metabolism and health. The improved growth and feed efficiency in the calves receiving sorbitol at rates of 0.12 up to $0.15 \mathrm{~g} / \mathrm{day} / \mathrm{kg}$ liveweight during the initial period were not entirely due to results obtained in week 8 . At this age, both groups were coldstressed accidentally, but the liveweight gain of the sorbitol group had been about $100 \mathrm{~g}$ per day higher than that of the control group during the first 7 weeks, and the sorbitol group withstood this stress better than the controls. Their refusal frequency and quantities were about three times lower.

According to Daniels et al. (1981), the effect of sorbitol on feed efficiency would be maximal at this age with a dose of $20 \mathrm{~g} / \mathrm{day}(0.5 \mathrm{~g} / \mathrm{day} / \mathrm{kg}$ liveweight) but the risk of diarrhoea is increased. As a matter of fact, these disturbances could be due to the slow absorption of sorbitol, leading to increased osmotic pressure in the intestinal lumen, as in rats (Koopmans and Maggio, 1978).

During the fattening period, the intake of 11 to $30 \mathrm{~g} / \mathrm{d}(0.15 \mathrm{~g} / \mathrm{d} / \mathrm{kg}$ liveweight) improved liveweight gain (NS) and feed efficiency. This could be the result of a lower feeding level between weeks 9 and 14 and a lower dietary lipid content (21\% DM). This lower feeding level led to the recovery and satisfactory growth observed in the control calves and allowed the trial to be continued, but the improving influence of sorbitol was not evident in such conditions. In the last period (weeks 15 to 19), the feeding level was increased again, leading to improvement in growth and feed efficiency of the calves receiving sorbitol. These results are similar to those obtained by Thivend (1982), but the effects are not significant due to the smaller number of animals used.

On the whole, the better results of calves fed sorbitol, paralleled by systematically lower standard errors, seemed to rely on the fact that some of the control 
calves would have been unable to tolerate the high feeding level offered due to some weakness in their organism ; as in animals under nutrition stress, this would have led to a lower protein anabolism (Waterlow, Garlick and Millward, 1978) and then to decreased liveweight gain and feed efficiency.

\section{Conclusion.}

The addition of sorbitol to a milk substitute improves the liveweight gain and feed efficiency of calves and protects them from many harmful effects of nutritional and environmental stress. The results of sorbitol intake are not related to improved feed digestibility (already high in the control group) but to improved feed efficiency which, without sorbitol, is considerably lower with overfeeding (namely excessive lipid intake) or during other situations of stress or fatigue to the organism. The lower standard errors of calves receiving sorbitol underline the protective and regulating influence of sorbitol on the functions of the organism and show it to be a safeguard in animal rearing.

The effects of sorbitol are evident at all stages of growth from birth to slaughter at $200 \mathrm{~kg}$ liveweight, provided the amount introduced into the diet is of the order of 0.12 to $0.15 \mathrm{~g} / \mathrm{day} / \mathrm{kg}$ liveweight of sorbitol.

Reçu en juin 1984.

Accepté en novembre 1984.

Acknowledgements. - The authors are very grateful to the company " Roquette Frères » (62136 Lestrem, France) for financial help and the sorbitol determinations and to P. Thivend and his team for technical assistance.

Résumé. Addition de sorbitol à un lait de remplacement pour veaux de boucherie. - I. Influence sur les performances zootechniques.

Deux groupes homologues de 10 (lot témoin) et 9 (lot sorbitol) veaux mâles préruminants croisé Frisons $\times$ Holstein ont été utilisés pour étudier les effets du sorbitol sur leur appétit, leur état sanitaire et leur vitesse de croissance. Ils ont reçu, entre les âges de 1 et 8 semaines, 2 aliments d'allaitement (IT, IS) riches en protéines et en matières grasses $(23 \%$ de MS), puis entre les âges de 8 et 19 semaines, 2 aliments (FT, FS) dont les teneurs en protéines et en matières grasses étaient plus faibles (21\% de MS). Les aliments IT et FT étaient dépourvus de sorbitol, tandis que les aliments IS et FS en comprenaient $0,8 \%$ par rapport à la matière sèche. Dans chaque groupe, 4 à 6 veaux ont été utilisés pour mesurer la digestibilité des laits à 3,7 et 12 semaines. A l'abattage, à 19 semaines, la qualité des carcasses et l'état du foie des animaux ont été contrôlés.

L'état sanitaire de l'ensemble des animaux a été satisfaisant, mais après un refroidissement survenu en septième semaine, les 10 veaux du lot témoin ont été atteints durant 2 à 5 jours de diarrhées contre 4 dans le lot sorbitol.

La digestibilité du sorbitol a été de l'ordre de $95 \%$ en troisième semaine et quasiment totale en $7^{\mathrm{e}}$ et en $12^{\mathrm{e}}$ semaines. Les digestibilités apparentes de l'énergie et des protéines ont augmenté pour les deux lots de 83,8 et de $83,1 \%$, respectivement en $3^{\theta}$ semaine à 89,8 et $90,7 \%$, à partir de la $7 \mathrm{e}$ semaine, mais n'ont pas été influencées par le sorbitol. 
Le gain de poids vif $(+12 \%$ pour la totalité de l'essai) et l'efficacité alimentaire des animaux $(+6,7 \%$ pour la totalité de l'essai) ont été significativement $(P<0,05)$ améliorés par la présence de sorbitol dans la ration.

\section{References}

BAUCHART D., AUROUSSEAU B., AUCLAIR E., LABARRE A., 1985. Addition of sorbitol to a milk replacer for preruminant calves. II. Effect on plasma, liver and muscle lipids. Repr. Nutr. Dévelop., 25, 411-425.

BESLE J. M., LASSALAS B., THIVEND P., 1980. Digestion des glucides de la levure d'alcanes par le Veau préruminant. Reprod. Nutr. Dévelop., 20, 1401-1414.

DANIELS L. B., PETERSON R. L., PIPER E. L., RAKES J. M., 1981 . Sorbitol in diet of young dairy calves. J. Dairy Sci, 64, 449-453.

FOLCH J., LEES M., SLOANE-STANLEY G. H., 1957. A simple method for the isolation and purification of total lipids from animal tissues. J. biol. Chem., 226, 497-509.

HOSHI M., 1963. Clinical application of sorbitol in patients with diabetes melitus and in patients with liver disease. Med. J. Osaka Univ., 14, 47-60.

HUBER J. T., JACOBSON N. S., ALLEN R.S., 1961. Digestive enzyme activities in the young calf. J. Dairy Sci., 44, 1494-1501.

KOOPMANS H. S., MAGGIO C. A., 1978. The effects of specified chemical meals on food intake. Amer. J. Nutr., 31, 267-272.

KUSSAIBATI R., LECLERCQ B., 1984. Effects of sorbitol and added bile salts on food utilisation and morphological changes in the liver, gall bladder and caeca of young chicks. Ann. Zootech., 33, 51-58.

MOULLART C., 1959. Que peut-on attendre du sorbitol en gastroentérologie ? Le Concours Médical, $11,659-660$.

PORCHER P., 1957. Le sorbitol, un accélérateur inattendu du transit intestinal. Arch. Mal. App. dig., 46, 663-665.

THIVEND P., 1979. La digestion des glucides chez le veau non sevré. Ann. Nutr. Alim., 33, 233-245.

THIVEND P., 1982. Influence du sorbitol dans I'alimentation du veau de boucherie. Bull. Tech. CRZV Theix, INRA, 50, 47-50.

THIVEND P., DEBARRE M., LEFAIVRE J., TOULLEC R., 1984. Influence of sorbitol on biliary secretion in the preruminant calf. Can. J. anim. Sci., 64 (supplement), 102-103.

TOULLEC R., THIVEND P., VERMOREL M., GUEGUEN L., 1978. Le veau, 270-271. In INRA, Alimentation des Ruminants, Ed. INRA publications, Versailles.

VERMOREL M., BOUVIER J. C., BONNET Y., FAUCONNEAU G., 1973. Construction et fonctionnement de 2 chambres respiratoires du type " circuit ouvert " pour jeunes bovins. Ann. Biol. anim. Bioch. Biophys., 13, 659-681.

WATERLOW J. C., GARLICK P. J., MILLWARD B. J., 1978. Protein turnover in mammalian tissues and in the whole body. In Chapiter 18. The effects of nutrition and hormones on protein turnover in muscle. Elsevier, Biomed. Press, Amsterdam, North-Holland.

WATSON J. D., YUDKIN J., 1959. Effect of sorbitol on the urinary excretion of some B vitamins in man. Nature, 104, 911. 